\title{
Preliminary data on the bog surface wetness from the Sirok Nyírjes-tó peat bog, Mátra Mts, Hungary
}

\author{
Gusztáv Jakab \\ Institute of Environmental Sciences \\ Szent István University, Szarvas
}

\author{
Pál Sümegi \\ Department of Geology and Paleontology \\ University of Szeged, Szeged
}

\begin{abstract}
The Sirok Nyírjes-tó peat bog provides an almost full Holocene climatic record reconstructed by bog surface wetness investigations based on plant macrofossil analysis. The method of bog surface wetness reconstruction has not so far been adapted to the characterization of continental peat bogs. The emergence of a deep oligotrophic lake was dated to cc. $9500 \mathrm{cal}$. yr BP. The driest phase of the peatland was recorded at $6400 \mathrm{cal}$. yr BP, at the time of the Holocene climatic optimum. The deterioration of the climate, which began at $3500 \mathrm{cal} \mathrm{BP}$, culminates here in the Carpathian Basin, as was shown by numerous records. An increase in the amount of Sphagna from $2800 \mathrm{cal}$. yr BP in the Nyires-tó peat bog marks the cooling of the climate and the accompanying rise in rainfall. The first oligotrophic Sphagnum peatland developed at Sirok between 2300 and $1500 \mathrm{cal}$. yr BP. Since $2300 \mathrm{cal}$. yr BP a record of alternating phases of Sphagnum peatlands and sedge/reed peatlands was demonstrated. A sudden expansion of Sphagna was recorded at least 10 times. Sphagnum-peaks at $2150,1750,1300,1000,850,500$ and 200 cal. yr BP perfectly match the humid periods identified in western Europe.
\end{abstract}

Key words: Holocene, climate reconstruction, plant macrofossils, peat bog, Sphagnum, Holocene climatic optimum, Little Ice Age

\section{Introduction}

The first Holocene millenial-scale climatic scheme was based on the studies of peat stratigraphy in Scandinavia a century ago (Blytt 1876; Sernander 1908). This widely applied scheme was recognized as too simplistic and not realistic. On the basis of high-latitude ice-core data Holocene climate is considered relativily even

Addresses: G. Jakab: H-5540 Szarvas, Szabadság u. 1-3. Hungary, e-mail: cembra@freemail.hu P. Sümegi: H-6722 Szeged, Egyetem u. 2-6. Hungary, e-mail: sumegi@geo.u-szeged.hu Received: September 14, 2010; accepted: January 11, 2011 
and invariable (Oldfield 2005). Climate fluctuation of the Holocene has been now a major research focus in Quaternary paleoecology, because these proxy-climate data archives can be compared with the recent global warming.

One of the most popular approaches is looking for proxies reflecting transformations in the biological and chemical composition of peat sequences as signals of past climatic fluctuations. A frequently used approach in chemical analysis is the investigation of humification (Aaby 1976; Barber 2007). This approach relies on the logic that surface humidity ultimately determines the rate of decay of plant matter. When peatlands are dried out, this is reflected in a sudden increase in humic acids within the deposits. These acids are extracted from the deposits using various alkalis and their concentration is determined in the solution by spectrophotometric approaches.

The most widely adopted method in the analysis of biological components is the study of plant macrofossils, including mosses or testacea (Hughes et al. 2000; Barber and Langdon 2001; Barber and Charman 2005; Birks 2007; Mauquoy and van Geel 2007). These studies enable us to identify various peatland types and past communities. However, there is a special feature of peatland plants that can aid the interpretation of earlier environmental conditions. Certain species are distributed along a gradient reflecting differing water depths. Bog surface wetness investigations using the QLCMA technique (semi-quantitative quadrat and leaf-count macrofossil analysis technique) of Barber et al. (1994) permitted high-resolution reconstruction of past climatic changes. Former bog surface wetness studies aimed at deciphering past climatic conditions via detailed analysis of peatland deposits, primarily focusing on the investigation of Sphagnum peat from so-called ombrotrophic peatlands (Mauquoy and Barber 1999; Barber et al. 2000; Blackford 2000; Barber and Langdon 2001; Barber and Charman 2005). Climatic conditions favoring the evolution of these type of peatlands are mainly restricted to the western parts of Europe under oceanic climatic influence (Barber and Charman 2005; Barber 2007) or in Fennoscandinavia (Väliranta et al. 2007), where the moisture gradient is unambiguously reflected in the distribution of certain Sphagnum taxa; no discussion, however, occurs on SE Europe, including Hungary. Barber and Charman (2005) questioned the suitability of strongly continental peatlands for paleoclimatic reconstructions. This area appears blank on the data source maps, pointing to the paucity of available Holocene bog surface wetness records in this region (Buczkó et al. 2009).

The general climatic characteristics of Hungary are far from ideal for the emergence of Sphagnum peatlands. The majority of Sphagnum peatlands are restricted to the northern areas of the North Hungarian Range and the northern Great Hungarian Plain (GHP), as well as the eastern parts of the country enjoying more precipitation thanks to the positive effect of the oceanic and montane climatic influences (Boros 1968; Szurdoki and Nagy 2002). The actual number of Sphagnum peatlands is below 20, the majority being tiny, with an 
extension of a couple of ha. Raised bogs are completely absent. After the artificial desiccation of Sphagnum peatlands there is an advance of reed, sedge and birch into these areas, depending on local availability (Borhidi and Sánta 1999; Lájer 1998). The bulk of Hungarian peat mosses can be found in fens and willow and alder swamps, where they create mixed-extent carpets, but the microtopography, as f.i. in Nordic mires (hummock, hollow, pool, etc.), are more or less absent. The most frequent species in bigger mires are Sphagnum angustifolium, S. fallax, S. palustre and S. fimbriatum, which are not able to build a hummock-hollow system. The species which could create a compact hummock (e.g. S. capillifolium, S. rubellum, S. magellanicum) are very rare and show only scattered distribution in these mires. Hollow and pool-forming species are also absent except for some $S$. cuspidatum occurrences.

This paper presents the preliminary results of bog surface wetness investigations on the deposits of a Sphagnum-bog called Nyírjes-tó in the Mátra Mts (Fig. 1). Specific questions which we aim to address are:

1. Can we use the bog surface wetness method based on plant macrofossil analysis to obtain a proxy-climate record under conditions of a strongly continental climate? Which are the most characteristic features of peat composition under wet and dry conditions?

2. Can we find any correspondence in the bog surface wetness record from Hungary and western Europe? How does the obtained bog surface wetness record correlate with other proxy-climate records from the Carpathian basin?

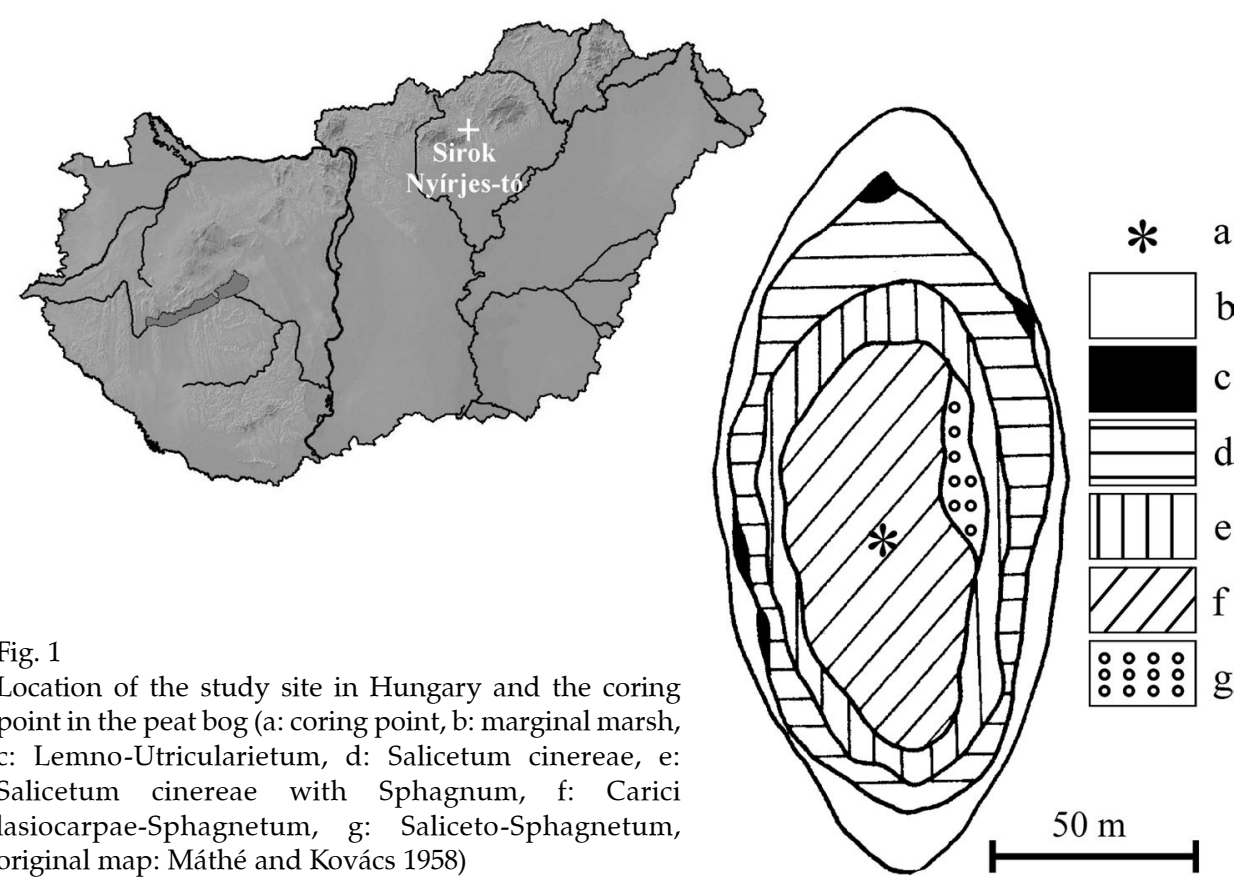




\section{Study site}

The location of the Nyírjes-tó peat bog of Sirok is situated in the northern part of the country, in the eastern foothills of the Mátra Mts, at an elevation of $250 \mathrm{~m}$ (Fig. 1). It covers a small area, of about $9,000 \mathrm{~m}^{2}$. No surficial watercourses feeding or draining the peatland are known. The basin is fringed by a woodland of hornbeam (Carpinus betulus) and oak (Quercus petraea). The following plant communities are present, moving from the margins towards the center: Salicetum cinereae, Salicetum cinereae-Sphagnetum, Carici lasiocarpae-Sphagnetum. There is a small stand of reedbed on the eastern side of the peat bog. This peatland harbors the following peat moss taxa: Sphagnum palustre, S. subsecundum, S. magellanicum, S. recurvum s. 1., S. fimbriatum, S. squarrosum, S. obtusum and S. angustifolium. The most common are those of Sphagnum recurvum s. 1. and S. palustre (Máthé and Kovács 1958; Szurdoki and Nagy 2002).

Szurdoki (2005) investigated the abiotic conditions of some of the most frequent Sphagnum, in five Hungarian mires, among others the Nyírjes-tó peat bog. Conductivity, $\mathrm{pH}$, height above water table, $\mathrm{Na}, \mathrm{K}, \mathrm{Ca}$ and $\mathrm{Mg}$ concentrations were detected. The investigated peat bogs were similar, but there were many significant differences between them in terms of analytical variables, and only weak differences within mires. On the basis of water table, $\mathrm{pH}$, and conductivity the investigated species can be separated. S. fallax and S. angustifolium do not differ from each other, which is not a surprise since they live together in mixed carpets in most investigated mires. They mainly occur in wet and acidic locations with poor mineral content. S. palustre lives in the driest places and S. fimbriatum in wet and less acidic ones, which are characterized by the highest mineral content.

According to Szurdoki (2005) the most characteristic features of the Hungarian peat bogs are low $\mathrm{pH}$ (c. $\mathrm{pH} 4$ ) and conductivity of $40-80 \mu \mathrm{S} / \mathrm{cm}$; however, the concetration of calcium proved to be relatively high $\left(10 \mathrm{mg} / \mathrm{dm}^{3}\right)$ within a European context. The $\mathrm{pH}$ of the Nyírjes-tó surface peat layer fluctuated between 3.5 and 4.5 (Máthé and Kovács 1958; Szurdoki 2005). The concentration of nutrients and the water level of Nyírjes-tó is the lowest among the Hungarian peat bogs. The main water level is $17 \mathrm{~cm}$ from the peat surface, but in late summer it can be as low as $30 \mathrm{~cm}$ (Szurdoki 2005).

Penksza et al. (1994) investigated the heavy metal accumulation in peat and in peat-forming mosses and vascular plants from the Nyírjes-tó. Unfortunately the stratigraphic resolution was insufficient and radiocarbon dating was lacking. Therefore the comparison with our paleoecological results is problematic. A detailed palynological work on the peatland was published by Gardner (2002). The comparison of terrestrial and wetland vegetation development is based on the results of Gardner. 


\section{Methods}

The sampling of the $401 \mathrm{~cm}$ deep, undisturbed sedimentary sequences of the Nyírjes-tó Basin was carried out using a $5 \mathrm{~cm}$-diameter Russian-type corer (Jowsey 1966). Overlapping cores were extracted conforming to the general practice in Quaternary paleoenvironmental studies (Aaby and Digerfeldt 1986). Coring was carried out in the central part of the bog, now occupied by the Carici lasiocarpaea-Sphagnetum community. Samples taken between the depths of 401 and $4 \mathrm{~cm}$ were subjected to plant macrofossil analyses. The Psimpoll program (Bennett 1992) was used for plotting the analytical results.

The main lithostratigraphic features of the sedimentary sequence were determined and analyzed. For the description of the cores, the internationally accepted system and symbols of Troels-Smith, developed for unconsolidated sediments, was adopted (Troels-Smith 1955).

Dating of the sequence was carried out by conventional radiocarbon dating at the radiocarbon dating facility in Gliwicze, Poland. Four bulk samples (6-10 g peat) of sediment were analyzed for radiocarbon ages. In order to allow comparison with other archeological data, the dates were calibrated using the CalPal-2007 online calibration programme, using the most up-to-date CalPal2007 Hulu calibration data set (Weninger et al. 2008). The original dates $\left({ }^{14} \mathrm{C}\right)$ are indicated as BP, while the calibrated dates are indicated as cal BC/AD or cal BP. For a more accurate dating of the lower part of the core, additional radiocarbon measurements are under way.

For the description of macrofossils a modified version of the QLCMA technique (semi-quantitative quadrat and leaf-count macrofossil analysis technique) of Barber et al. (1994) (Jakab et al. 2004a) was used. To obtain concentrations for the macrofossil components, a known amount of marker grains ( 0.5 g poppy seeds, ca. 960 pieces) were added to the samples. In the diagrams the total number of seeds relates to $20 \mathrm{~cm}^{3}$ sediment, while other macrofossil components are expressed as concentrations (piece $\mathrm{cm}^{-3}$ ). Organic remains from peat and lacustrine sediments rich in organic matter can be divided into two major groups. Some remains can be identified with lower ranking taxa (specific peat components), while others cannot be identified using this approach (non-specific peat components). The most important non-specific peat components are the following:

- Unidentified organic material (UOM): irregularly shaped tissue fragments, often moderately decomposed.

- Undifferentiated monocotyledon remains (Monocot. undiff.): opaque or slightly pigmented rhizomes and epidermal tissue fragments, with elongated or short cells.

- Unidentified bryophyte fragments (UBF): Only the tubular, brown pigmented "stem" survives in decomposed peat with the stub of the "leaf veins".

- Unidentifiable leaf fragments (ULF): Moderately humified deciduous tree leaf fragments. Easily recognizable by the remains of web-like veins. 
- Charcoal: Tiny, 1-3 mm large charcoal fragments (macro-charcoal), probably of allochthonous origin.

- Wood: Lignified plant tissues can be easily recognized from their compact, thick-walled wood fibres.

\section{Results}

\section{Chronology and sediment stratigraphy}

On the basis of the sedimentological features the core was divided into 12 units. In general mixed Sphagnum, reed and sedge peat was found down to a depth of $210 \mathrm{~cm}$. Between 210-300 cm mixed reed and sedge peat was encountered; between 300-340 cm occurred a brown moss peat with high wood content. Between 340-410 cm dark gray, silty lacustrine sediments were found with wood and moss fragments. The detailed sediment description is presented in Table 1.

Table 1

Lithological description of the Nyírjes-tó sequence (Sümegi and Jakab)

\begin{tabular}{|c|l|l|}
\hline $\begin{array}{c}\text { Depth } \\
(\mathrm{cm})\end{array}$ & \multicolumn{1}{|c|}{$\begin{array}{c}\text { Troels-Smith (1959) } \\
\text { sediment description }\end{array}$} & \multicolumn{1}{c|}{ Lithological characteristics } \\
\hline $0-20$ & $\mathrm{~Tb}$ (Sphag.)4Th+As+Gs+ & Light brown fresh Sphagnum peat with little silt and sand \\
\hline $20-60$ & $\mathrm{~Tb}$ (Sphag.)2Th2 & Light brown mixed Sphagnum, reed and sedge peat \\
\hline $60-80$ & $\mathrm{~Tb}$ (Sphag.)4Tl+ & Dark brown Sphagnum peat \\
\hline $80-120$ & $\mathrm{Th} 3 \mathrm{~Tb} 1 \mathrm{Tl}+$ & $\begin{array}{l}\text { Dark brown mixed Sphagnum, reed and sedge peat with wood } \\
\text { fragments }\end{array}$ \\
\hline $120-160$ & $\mathrm{~Tb}($ Sphag.)3Th1Tl+ & Dark brown mixed Sphagnum and reed peat with wood fragments \\
\hline $160-185$ & $\mathrm{Th} 3 \mathrm{As} 1 \mathrm{~Tb}(\mathrm{Sphag})+.\mathrm{Tl}+$ & $\begin{array}{l}\text { Dark brown mixed reed and sedge peat with wood fragments and } \\
\text { Spagnum remains }\end{array}$ \\
\hline $185-210$ & $\mathrm{~Tb}(\mathrm{Sphag}) .4 \mathrm{Th}+\mathrm{Tl}+$ & Dark brown Sphagnum peat with wood, reed and sedge fragments \\
\hline $210-285$ & $\mathrm{Th} 2 \mathrm{As} 1 \mathrm{Tl1} \mathrm{Tb}(\mathrm{Sphag})+$. & $\begin{array}{l}\text { Dark brown mixed reed and sedge peat with some Sphagnum } \\
\text { remains and many wood fragments }\end{array}$ \\
\hline $285-300$ & $\mathrm{Th} 3 \mathrm{As} 1 \mathrm{Tl}+\mathrm{Tb}+$ & Dark brown Carex elata peat \\
\hline $300-340$ & $\mathrm{~Tb} 2 \mathrm{As} 1 \mathrm{Tl1} \mathrm{Th}+$ & Dark brown brownmoss peat with many wood fragments \\
\hline $340-360$ & As2Ag2Gs + & Dark grey clayey silt \\
\hline $360-410$ & As3Sh1Gs $+\mathrm{Tb}+\mathrm{Dg}+$ & Dark grey clayey silt with moss and wood fragments and some sand \\
\hline
\end{tabular}

The results of the radiocarbon measurements of the sequence described in this study are shown in Table 2 . The age-depth model was established by linear interpolation between the calibrated radiocarbon dates (Fig. 2). Sedimentation rates are shown in Table 3. The bottom part of the investigated part of the core, between $195-315 \mathrm{~cm}$, is characterized by very low values $\left(0.25 \mathrm{~mm} \mathrm{yr}^{-1}\right)$; the sedimentation rate increases gradually between $38-195 \mathrm{~cm}$ from 0.25 to $1.16 \mathrm{~mm}$ $\mathrm{yr}^{-1}$, and attains the highest values in the top $38 \mathrm{~cm}$ of the core $\left(3.39 \mathrm{~mm} \mathrm{yr}^{-1}\right)$. 
Table 2

Radiocarbon data from the Nyírjes-tó (Sümegi)

\begin{tabular}{|c|c|c|c|c|}
\hline Sample No & Depth $(\mathrm{cm})$ & Sample type & $\begin{array}{c}{ }^{14} \mathrm{C} \text { age } \\
(\text { uncal BP })\end{array}$ & $\begin{array}{c}\text { cal AD/BC } \\
(2 \sigma)\end{array}$ \\
\hline GdA-565 & $37-38$ & Bulk sediment (peat) & $55 \pm 30$ & $1889 \pm 83$ \\
\hline GdA-566 & $99-100$ & Bulk sediment (peat) & $560 \pm 30$ & $1364 \pm 41$ \\
\hline GdA-567 & $195-196$ & Bulk sediment (peat) & $1680 \pm 30$ & $353 \pm 41$ \\
\hline GdA-568 & $315-316$ & Bulk sediment (peat) & $5640 \pm 40$ & $4465 \pm 52$ \\
\hline
\end{tabular}

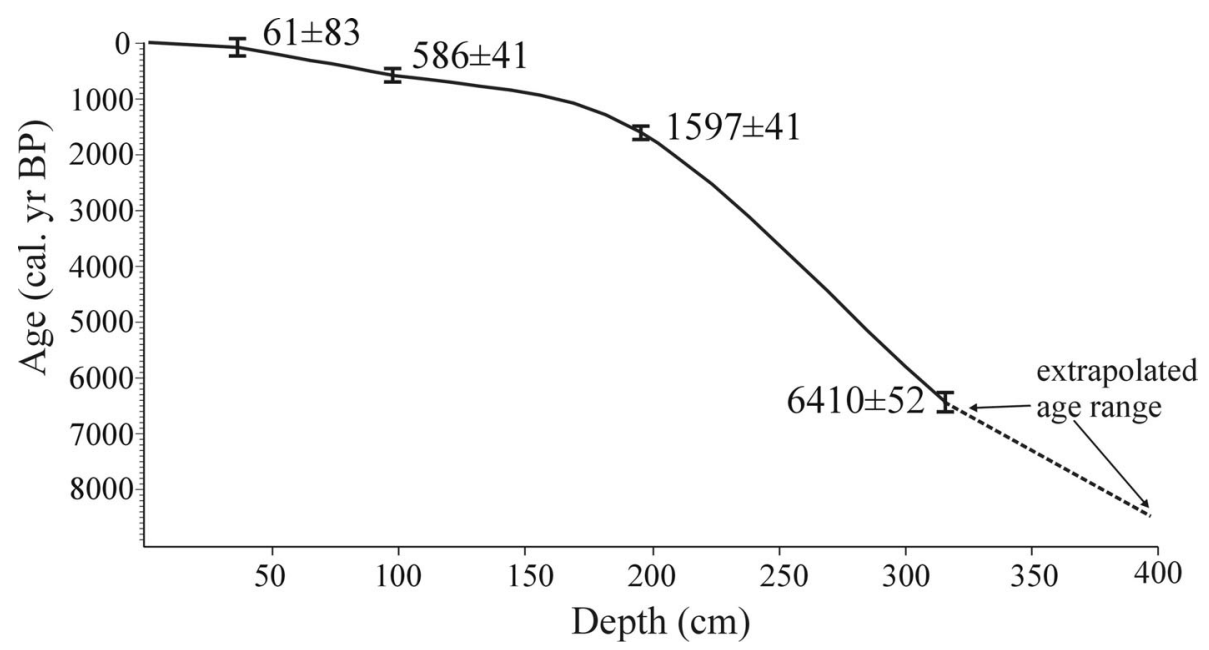

Fig. 2

Calibrated radiocarbon age ranges (1) and suggested age-depth curve for core SI (Sirok Nyírjes-tó). All dates were converted into calendar years BP using the CalPal-2007 online calibration program (Danzeglocke et al. 2008). See also Table 3 (Sümegi and Jakab)

These sedimentation rates are related to the sediment types accumulated in the basin. Above $210 \mathrm{~cm}$ Sphagnum and reed peat can be found with high organic content. Subsamples for macrofossil analysis were taken at $4 \mathrm{~cm}$ intervals, which correspond to 40-50 yr resolution in the last 2000 years and 130-150 yr resolution before 2000 yrs BP. Nevertheless the resolution of radiocarbon dating in the lower 2 meters is unsatisfactory, so a more accurate stratigraphic resolution requires further radiocarbon measurements.
Table 3

Sediment accumulation rates from the Nyírjes-tó sequence

\begin{tabular}{cc}
\hline $\begin{array}{c}\text { Depth ranges } \\
(\mathrm{cm})\end{array}$ & $\begin{array}{c}\text { Sediment accumulation rates } \\
(\mathrm{mm} / \mathrm{yr})\end{array}$ \\
\hline $0-38^{*}$ & 3.39 \\
$38-99$ & 1.16 \\
$99-195$ & 0.95 \\
$195-315$ & 0.25 \\
\hline
\end{tabular}

*The age of the upper point concerned AD 2007 (Sümegi and Jakab) 


\section{Terrestrial and wetland vegetation development}

Figure 3 displays the tissue, moss, animal and seed remains extracted from the investigated sequence. Table 4 presents the most important characteristics of the local macrofossil zones. On the basis of the results the following evolutionary history of the peatland and the sorrounding watershed can be drawn.

Table 4

Discussion of the macrofossil assemblages of the Nyírjes-tó sequence (Jakab)

\begin{tabular}{|c|c|c|c|}
\hline $\begin{array}{l}\text { Depth } \\
(\mathrm{cm})\end{array}$ & $\begin{array}{c}\text { Age } \\
\text { (cal. yr BP) }\end{array}$ & $\begin{array}{l}\text { Local macro- } \\
\text { fossil zone }\end{array}$ & Yone description \\
\hline $32-6$ & $61-$ & SIM-9 & $\begin{array}{l}\text { Degrading oligotrophic peat bog conditions. Beside the high } \\
\text { amount of Sphagnum recurvum, the leaves of } S \text {. squarrosum and } \\
S \text {. palustre indicate gradual eutrofication. Clay particles and } \\
\text { mollusc shells indicate soil erosion in the catchment. Calamagrostis } \\
\text { canescens and Carex lasiocarpa were the most common vascular } \\
\text { plants. }\end{array}$ \\
\hline $71-32$ & $380-61$ & SIM-8 & $\begin{array}{l}\text { Dry oligotrophic peat bog conditions. Sphagnum concentrations } \\
\text { decrease, Carex elata and Phragmites concentrations rise. Juncus } \\
\text { sp. remains indicate degradation. }\end{array}$ \\
\hline $88-71$ & $500-380$ & SIM-7 & $\begin{array}{l}\text { Wet oligotrophic peat bog conditions. Beside the dominant } S \text {. } \\
\text { recurvum s. } 1 ., \text {. cuspidatum show a remarkable peak. Peat bog } \\
\text { vegetation dominated by Calamagrostis canescens, Carex } \\
\text { lasiocarpa, C. canescens, C. limosa and Eriophorum vaginatum. } \\
\text { Occurrence of Sphagnum cuspidatum and Carex limosa indicates } \\
\text { conditions wetter than now. }\end{array}$ \\
\hline $188-88$ & $1500-500$ & SIM-6 & $\begin{array}{l}\text { Macrofossil concentrations show remarkable fluctuations in this } \\
\text { zone. High concentrations of reed and peat moss remains alternate } \\
\text { from time to time. The first Sphagnum peaks dominated by } S \text {. } \\
\text { obtusum, and later by later } S \text {. subsecundum, S. magellanicum and } S \text {. } \\
\text { recurvum s. l., were typical. }\end{array}$ \\
\hline $213-188$ & $2300-1500$ & SIM-5 & $\begin{array}{l}\text { Oligotrophic peat bog conditions with high concentrations of } \\
\text { Sphagnum leaves (mostly S. magellanicum), Carex lasiocarpa and } \\
\text { C. rostrata rhizomes and Betula remains. }\end{array}$ \\
\hline $284-213$ & $5200-2300$ & SIM-4 & $\begin{array}{l}\text { Amount of Quercus remains decreased caused by rising water } \\
\text { level. Pond weeds (e.g. Potamogeton natans), weeds living on wet } \\
\text { mud (e.g. Rorippa amphibia) and planctonic invertebrates (e.g. } \\
\text { cladocera species) were characteristic of this zone. Lakeshore } \\
\text { vegetation dominated by Carex elata, C. paniculata, C. pseudo- } \\
\text { cyperus and Glyceria maxima. Later Phragmites, Carex rostrata } \\
\text { and Typha angustifolia become dominant. A short peat bog } \\
\text { expansion was detected at ca. } 3900 \text { cal. yr BP, with Sphagnum } \\
\text { magellanicum, S. palustre, S. recurvum s. 1. and Eriophorum } \\
\text { vaginatum. }\end{array}$ \\
\hline 299-284 & $\begin{array}{c}\text { cc. } 5800- \\
5200\end{array}$ & SIM-3 & $\begin{array}{l}\text { High macrofossil concentrations. Shallow mesotrophic mire } \\
\text { conditions with higher water levels. Hummock-hollow structure } \\
\text { with Carex elata and Menyanthes trifoliata. }\end{array}$ \\
\hline $343-299$ & $\begin{array}{c}\text { cc. } 7500- \\
5800\end{array}$ & SIM-2 & $\begin{array}{l}\text { High macrofossil concentrations. Shallow mesotrophic mire } \\
\text { conditions, with fluctuating water level and abundant brown moss } \\
\text { carpet. Remains (bud scale, leaf fragments, seeds) of Quercus were } \\
\text { quite frequent in this zone. The rhizomes of Phragmites australis, } \\
\text { Carex elata, C. paniculata, Glyceria maxima and the moss } \\
\text { Drepanocladus aduncus dominated the macrofossil record. A short } \\
\text { peat bog expansion was detected at ca. } 6800 \text { cal. yr BP, when } \\
\text { Sphagna, Carex rostrata, C. pseudocyperus, C. lasiocarpa, } \\
\text { Thelypteris palustris and Meesia longiseta spread in the basin. }\end{array}$ \\
\hline $401-343$ & $\begin{array}{c}\text { cc. } 9500- \\
7500\end{array}$ & SIM-1 & $\begin{array}{l}\text { Low macrofossil concentrations. Deep oligotrophic lake } \\
\text { conditions., with a short peatland expansion at ca. } 8200 \text { cal. yr BP. } \\
\text { Lakeshore vegetation was dominated by Carex elata, Phragmites, } \\
\text { Sphagnum magellanicum and } S \text {. recurvum s. } 1 \text {. }\end{array}$ \\
\hline
\end{tabular}

Central European Geology 53, 2010 
Preliminary data on the bog surface wetness from the Sirok Nyírjes-tó peat bog, Mátra Mts, Hungary 51

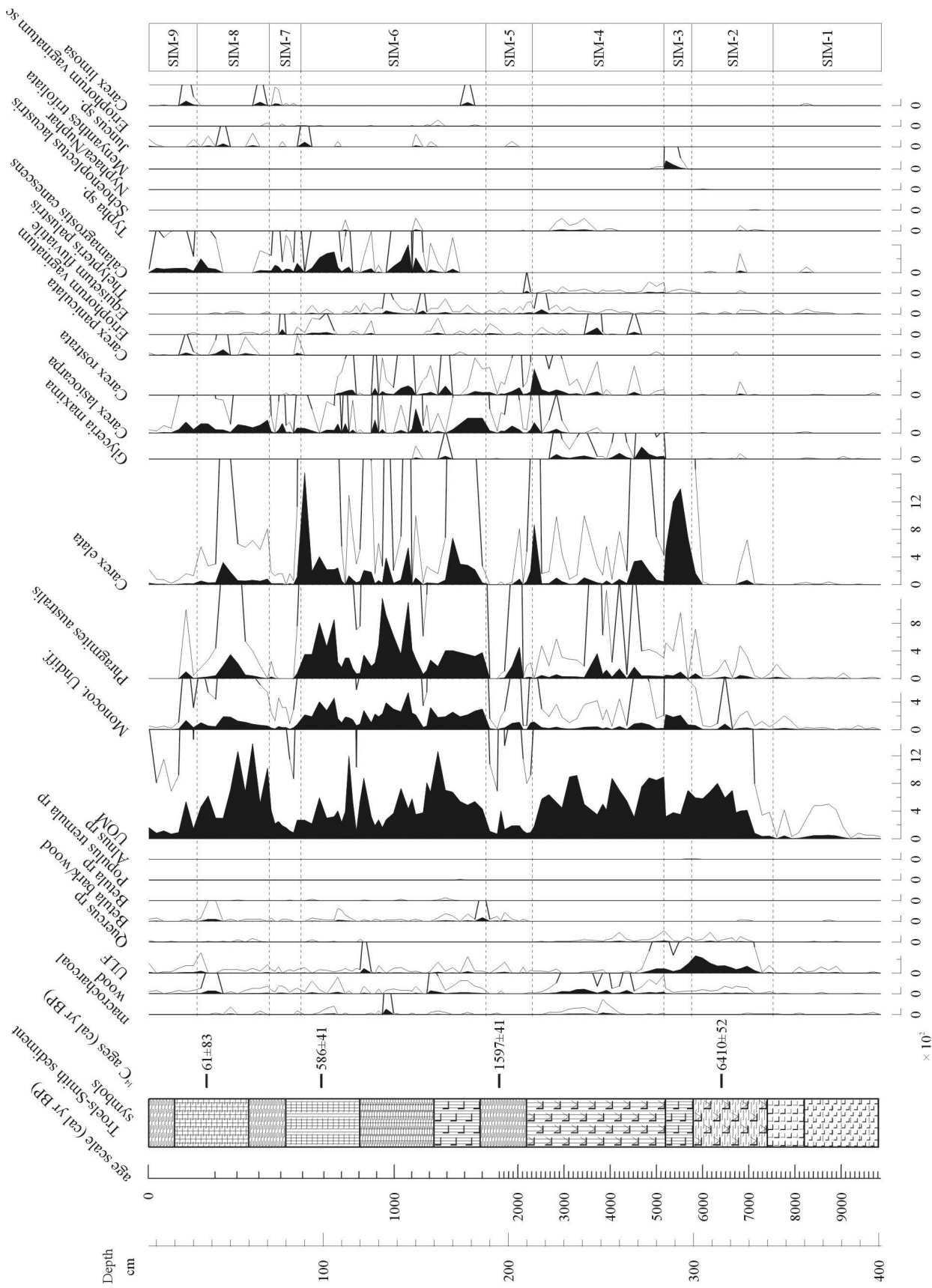

Fig. 3a

Macrofossil diagram of the Sirok Nyírjes-tó peat bog (tissues, pc/ $\mathrm{cm}^{3}$ ) (Jakab) 


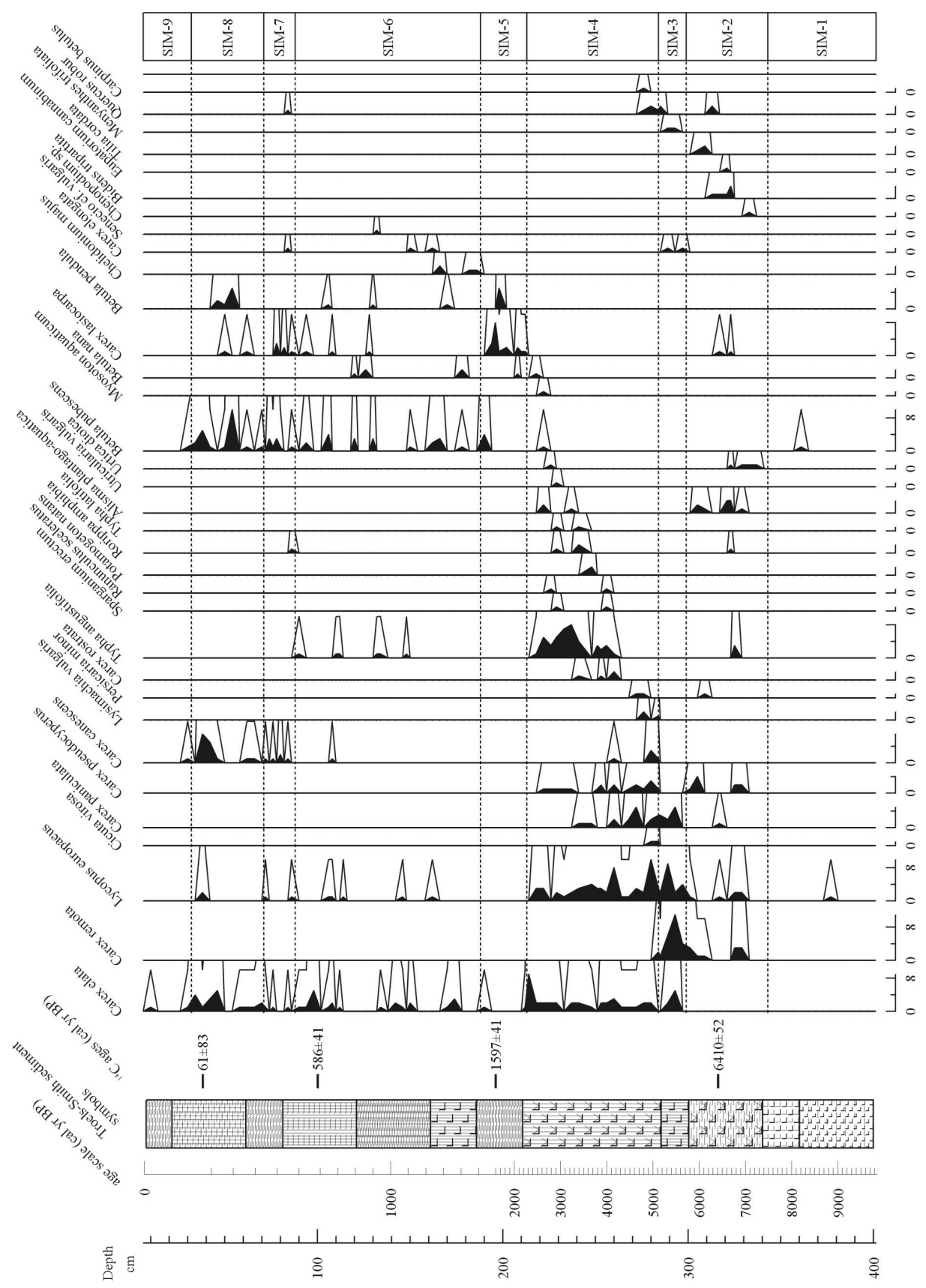

Fig. $3 b$

Macrofossil diagram of the Sirok Nyírjes-tó peat bog (seeds, $\mathrm{pc} / 20 \mathrm{~cm}^{3}$ ) (Jakab) 


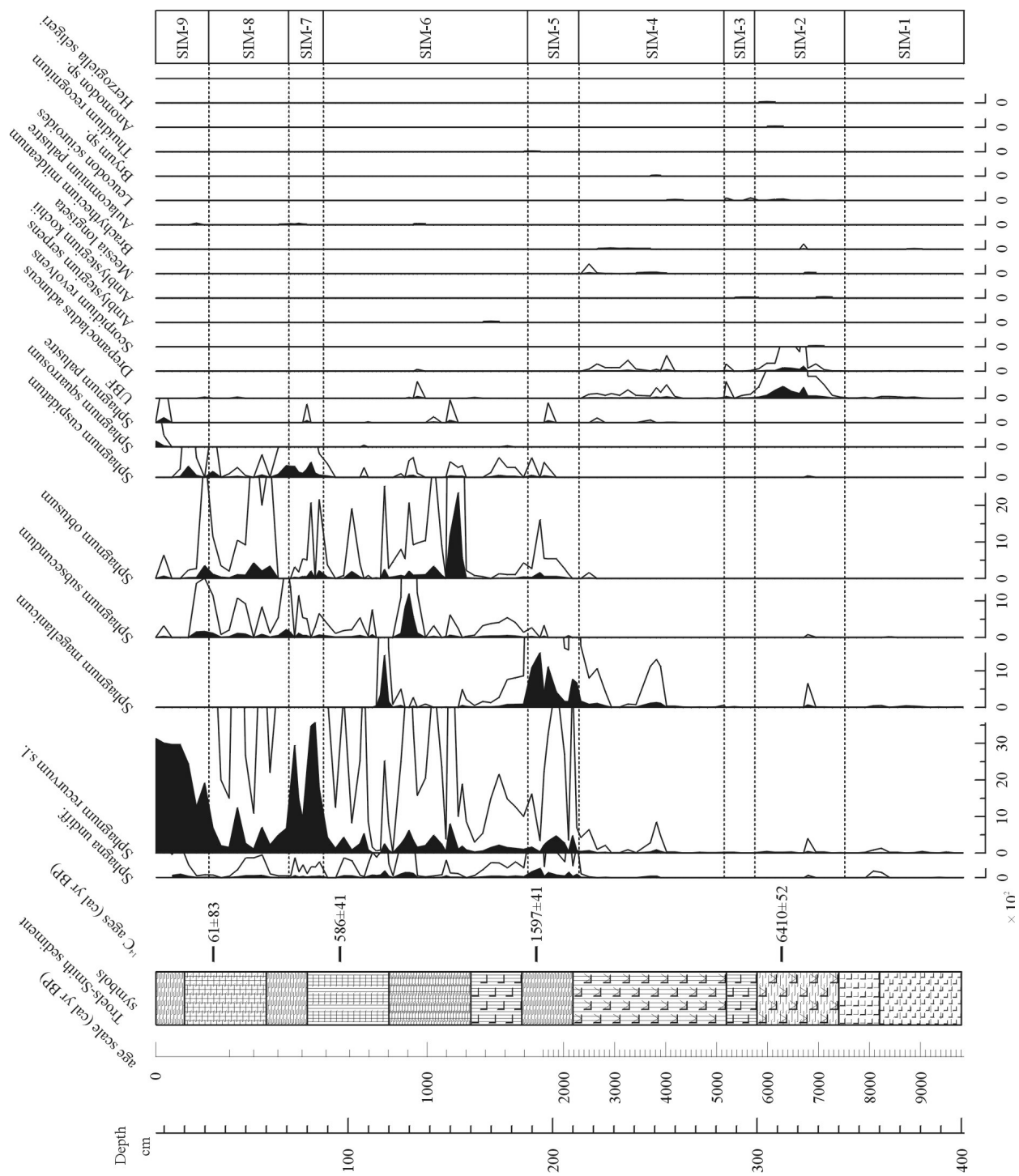

Fig. 3c

Macrofossil diagram of the Sirok Nyírjes-tó peat bog (mosses, pc/ $\mathrm{cm}^{3}$ ) (Jakab)

The first emergence of aquatic conditions in the depression can be dated to 9500 cal. yr BP, resulting in the emergence of a relatively deep, oligotrophic lake with scant aquatic vegetation. As shown by the palynological study of Gardner (2002) the lake basin was fringed by an open parkland-type woodland with 
predominance of Picea, Quercus and Corylus untill about 8950 cal. yr BP. This was transformed into a woodland dominated by Tilia until 8300 cal. yr BP, which was then finally transformed into a deciduous woodland dominated by Quercus, Tilia and Ulmus until 6900 cal. yr BP, with substantial stands of Corylus. Despite the clearly observable transformation of the surrounding vegetation, water levels remained relatively stable in the basin, apart from minor fluctuations, until 7500 cal. yr BP. A drop in water level (increasing concentrations of UOM, UBF and wood) and peat initiation took place almost 1000 years after the development of a closed, deciduous woodland. Therefore there is no direct link between the transformation of the vegetation of the peatland itself and the surrounding terrestrial areas. There is a gradual decrease in water levels from $7500 \mathrm{cal}$. yr BP, reaching an all time minimum at $6400 \mathrm{cal}$. yr BP. Open water areas almost completely disappeared, giving way to the expansion of oak shoots in the major part of the basin. The deepest areas turned into an eutrophic marshland and as such we must assume a gradual decrease in the water level from $5800 \mathrm{cal}$. yr BP, yielding a tussock vegetation. During this period the peatland was fringed by a woodland of Corylus, Quercus and Carpinus betulus (Gardner 2002).

There is another rise in the water level from $5200 \mathrm{cal}$. yr BP, resulting in the expansion of the peatland. This was accompanied by the appearance of floating mats in the expanding shallow eutrophic pond harboring peat mosses in larger amounts. There is a rapid spread of Carpinus betulus in the adjacent closed oak woodlands at that time (Gardner 2002). Peak distribution of Fagus sylvatica and Carpinus betulus was found between 3700 and 1750 cal. yr BP (Gardner 2002). A similar expansion of Sphagna is indicated by the macrofossil diagram after 3900 cal. yr BP in the basin, with the first appearance of real acidophyllic Sphagnum peatlands dated between 2300 and 1500 cal. yr BP.

From 1500 cal. yr BP there is an alternating succession of Sphagnum peatlands with reed and sedge peatland horizons, reflecting the alternations of cooler (Sphagnum peaks) and warmer (Phragmites peaks) periods up to the present day. Optimal Sphagnum peatland conditions were inferred at 500 cal. yr BP (AD 1550), with such taxa as Sphagnum cuspidatum. As shown by the results of Gardner (2002) there is an increase in human influence in the area from 1750 cal. yr BP as seen in the drop in the amount of Fagus and Carpinus, accompanied by an advent of Quercus.

The past century was also a period of Sphagnum peatland expansion. The presence of clayey horizons embedding mollusc shells and carbonate concretions intercalating the peat horizons are clear signs of soil erosion in the adjacent areas, triggered by deforestation of the nearby slopes. As an outcome of these activities the amount of rainfall reaching the surface substantially increased, resulting in an increase of the water level in the bed of the peatland and triggering the expansion of Sphagna. A similar phenomenon was described from several other European sites (Grosse-Brauckmann et al. 1973; Rybnícek and Rybnícková 1974; Rybnícková 1974). 
Changes in bog surface wetness

The climate reconstrucion is based on the plant macrofossil investigations of the peat sequence. Figure 4 presents the changes of the main macrofossil groups on the cal. BP timescale. In contrast to Fig. 3 this diagram shows the percentage values of the different macrofossil groups in the total macrofossil volume. Seeds, ephippia and other generative organs were excluded. This kind of data presentation removes the effect of the gradual decay of organic matter.

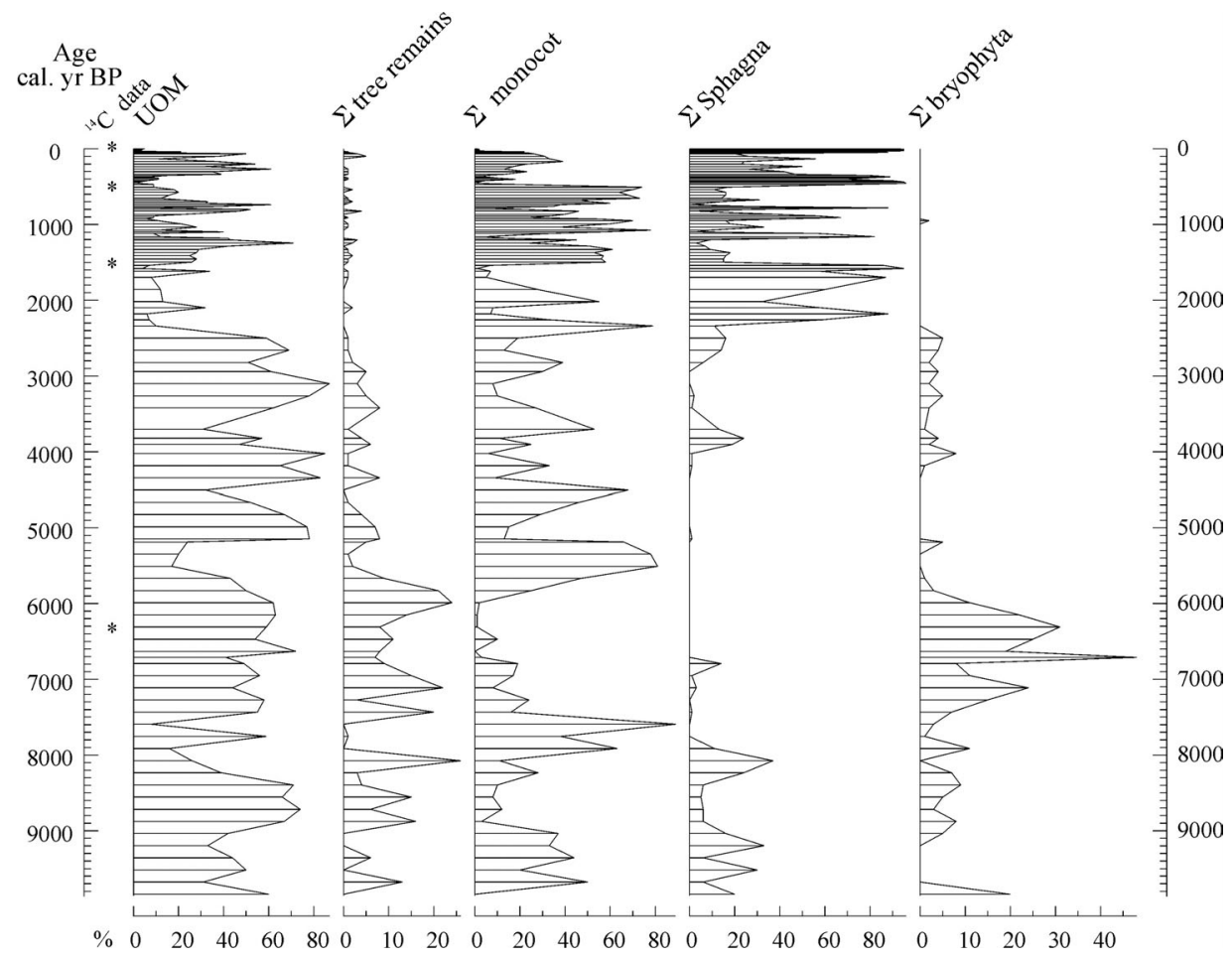

Fig. 4

Selected macrofossil diagram of the Sirok Nyírjes-tó peat bog

The most conspicuous feature of this diagram is the alternating amount Sphagna and monocot remains (together with UOM and tree remains). The spread of shrubs, trees and sedges at the expense of Sphagna due to the drainage or the present-day climate change is a well-known phenomenon of the Hungarian peat bogs, which are under strong continental climatic effects (Lájer 1998; Borhidi and Sánta 1999). It is an obvious assumption that the detected shifts in Sphagna percentages were triggered by climatic deteriorations (colder or more humid climate). Such climate deteriorations can be noticed at 8200, 6800, 3800, 
$2150,1750,1300,1000,850,500$ and 200 cal. yr BP. During these wet shifts different Sphagnum taxa become dominant in the basin, producing an unusual assemblage. According to the ecological investigations of Szurdoki (2005) the niche breadth of the different Sphagnum species in the Hungarian peat bogs was wide, with high overlap. Szurdoki (2005) argues that certain Sphagnum species utilize the different ecological resources similarly; therefore the competition between the different Sphagnum species is minimal. It is concluded that the strongly fluctuating environment caused the vanishing and re-establishment of Sphagna in the Hungarian peat bogs; therefore competition shortly after appearance determines the abundances. These frequently changing habitats produce strange species compositions.

The period between 7500 and $5200 \mathrm{cal}$. yr BP can be labeled as the driest part of the bog surface wetness history. The concentration of monocot remains is very low $(<5 \%)$; Sphagna remains are completely absent. In contrast UOM and tree remains (wood, ULF and budscales) show high peaks ( $>60 \%$ and $>20 \%$ ). Open water almost completely disappeared from the basin, and an oak forest occupied most of it.

\section{Discussion}

Investigations of the Sirok Nyírjes-tó peat bog provides an almost full Holocene record of vegetation development affected by climatic changes. The emergence of an oligotrophic lake in the area was dated to $9500 \mathrm{cal}$. yr BP, with deeper lake water conditions. Changes in the surficial moisture gradient of peatlands in the Carpathian Basin and those of lake level fluctuations are rather contradictory for this period. High lake-level phases are known at $8500 \mathrm{cal}$. yr BP for Szigliget Bay of Lake Balaton (Jakab et al. 2005; Sümegi et al. 2008), and Lake Nádas at Nagybárkány (Cserhát) (Jakab et al. 2009; Sümegi et al. 2009a). The inferred water levels of Lake Sf Ana in Romania show a highstand at $9500 \mathrm{cal}$. yr BP, with the emergence of a lowstand at 9000 cal. yr BP (Magyari et al. 2006, 2009). Conversely, studies implemented at various sites of the Great Hungarian Plain (Császártöltés) reconstructed a long-lasting dry and warm period till about 4400 cal. yr BP (Jakab et al. 2004a; Sümegi 2007; Sümegi et al. 2009b). There seem to be substantial regional differences in the Early and Middle Holocene climate of the Carpathian Basin.

Decreasing water levels inferred at $7500 \mathrm{cal}$. yr BP culminated in the driest phase of the peatland, recorded at $6400 \mathrm{cal}$. yr BP. This period is the time of Holocene climatic optimum, when there is a substantial retreat of the Swiss Alp glaciers between 7450 and 6650 cal. yr BP and between 6200 and 5650 cal. yr BP (Joerin et al. 2008). Conversely, there is an inferred increase in the water level of Lake Sf Ana in Romania from 7500 cal. yr BP onward, interrupted by a short decrease between 5500 and 5300 cal. yr BP (Magyari et al. 2006, 2009). According to Cheddadi et al. (1997) and Davis et al. (2003) the traditionally postulated 
Holocene climatic optimum is identifiable only in Northern Europe. At this time southern Europe was characterized by colder conditions, with Central Europe occupying a transitionary phase. This assumption is refuted by the findings of paleoecological studies made on lake and marshland basins in the Carpathian Basin.

Nevertheless the definition and limitation of the Holocene climatic optimum is ambiguous and depends on the geographic position and the type of applied methodology. Paleoclimatological reconstructions based on pollen analytical results from Hungary argue that the Holocene climatic optimum can be detected between 7000 and 8000 cal. yr BP (Magyari et al. 2001), or somewhat earlier between 7000 an 8100 cal. yr BP (Magyari et al. 2010).

Following the climatic optimum there are two periods when a substantial increase in the surface moisture gradient was observable in the referred study site: at 5800 and $5400 \mathrm{cal}$ yr BP. This change is congruent with the pattern observable in other lacustrine and marshland basins of the Carpathian Basin, also displaying an increase in the water level. There is a sudden increase in the water level of the Lake Sf Ana from 5500 cal. yr BP (Magyari et al. 2006, 2009) and Lake Balaton from 5200 cal. yr BP (Jakab et al. 2005; Sümegi et al. 2008). A somewhat delayed, similar pattern is observable in the peatlands of the GHP starting at 4400 cal. yr BP (Jakab et al. 2004a). This period between 5600 and 5300 cal. BP is referred to as the Middle Holocene Climatic Transition, characterized by a sudden deterioration of the previously warm conditions as a result of the collective transformation of orbital forces, solar activity and ocean currents (Magny et al. 2006; lizuka et al. 2008).

Three short-lived peat formation events were identified at 8200, 6800 and 3800 cal. yr BP, reflecting cooler conditions. Paleoecological records available from the Carpathian Basin have yielded no information of climate change for this period so far. There is a marked cooling related to a global cooling event lasting for merely 200 years, known as the '8.2 ky event' (Alley et al. 1997, Alley and Agústsdóttír 2005; Bond et al. 1997; Nesje and Dahl 2001). At 6000 cal. BP a high lake-level phase of Swiss lakes (Magny 1998; Magny and Schoellammer 1999) and changes in the moisture gradient of some British peatlands (Hughes et al. 2000) point to the emergence of cooler conditions. Similarly at 3500 cal. yr BP, the higher lake phase of Swiss lakes (Magny 1998; Magny et al. 2002), the expansion of Alpine glaciers (Haas et al. 1998), and an increase in the moisture gradient of numerous Western European peatlands marks a cooling of the climate (Hughes et al. 2000; Barber and Charman 2005). These Sphagnum shifts around 8200, 6800 and 3800 cal. yr BP at Nyírjes-tó coincide with the short-term climatic oscillations presented by Feurdean et al. (2008) using pollen-based climate reconstruction methods.

An increase in the amount of Sphagna from 2800 cal. yr BP in the Nyires-tó peat bog also marks a cooling of the climate and the accompanying rise in rainfall. This deterioration of the climate, starting at $3500 \mathrm{cal}$ yr BP, culminates 
here in the Carpathian Basin, as was shown by numerous records. Water levels were the highest in the Lake Sf Ana in Romania at this time, and there is information concerning the development of layering in the water body for this period (Magyari et al. 2006, 2009). Along with this data, information from studies of testacea and humic content of peatlands in the Eastern Carpathians show an increase in the moisture gradient (Schnitchen et al. 2003). The resuming peat formation in certain Hungarian peatlands marks the cooling of the climate here (Jakab and Sümegi 2007). On the whole these data suggest increasing moisture availability in the Carpathians and the adjoining Carpathian Basin from ca. 3400 yr BP, with maximum moisture availability around 2700-2800 years BP.

The first real acidophyllic Sphagnum peatland developed at Sirok between 2300 and $1500 \mathrm{cal}$. yr BP. From here on we have a record of alternating phases of Sphagnum peatlands and sedge/reed peatlands. As displayed by the record of vegetation changes, the catchment of the referred peatland was highly prone to climatic fluctuations. Certain periods are characterized by a rapid expansion of Sphagna, and others by the expansion of sedge and reed. A sudden expansion of Sphagna was recorded at least 10 times. Figure 5 displays a comparison of changes inferred from the Nyírjes-tó peat bog with cooler periods determined by Barber et al. (1994) and Mauquoy and Barber (1999), emphasizing changes for the last 3000 years. The Sphagnum peaks perfectly match the more humid periods identified in the British Isles at 2150, 1750, 1300, 1000, 850, 500 and 200 cal. yr BP (Barber et al. 1994; Mauquoy and Barber 1999; Barber and Charman 2005), indicating some collective global force as the cause for these changes. Barber and Charman (2005) identified centennial-scale climatic fluctuations in different parts of Western Europe. The length of these cycles was variable, spanning 210, 600, 800 or 1100 years in different peatlands. No such cycles have been identified in Central Europe so far.

The bog-surface wetness investigations with testate amoebae of Schnitchen et al. (2006) from the eastern Carpathians presented a period of greater variability in hydrological conditions after $3000 \mathrm{cal}$. yr BP. Significant shifts to wet conditions occurred, peaking at 2725, 2240,1665, 1170, 590 and $385 \mathrm{cal}$. yr BP. These wet shifts more or less coincide with the wet periods of the Nyírjes-tó (Fig. 5).

It is worth comparing paleoecological data of the site of the present study over the last 2000 years with those of written historical records. One major climatic crisis in the Carpathian Basin is connected to the fall of the Avar Empire in the 8th century AD. Written records blame famines and wars triggered by the extreme droughts during this period (Györffy and Zólyomi 1994; Györffy 1995). Little environmental historical data for this time has been available so far. As shown by the Sphagnum curve of our referred study site, this period was indeed characterized by dry conditions (Fig. 5).

Another major historical crisis was the appearance of Mongol tribes in the area in 1241-1242. Certain sources blame this on severely cold weather, while others talk about the extreme droughts (Kiss 2000, 2003). As shown by our paleo- 


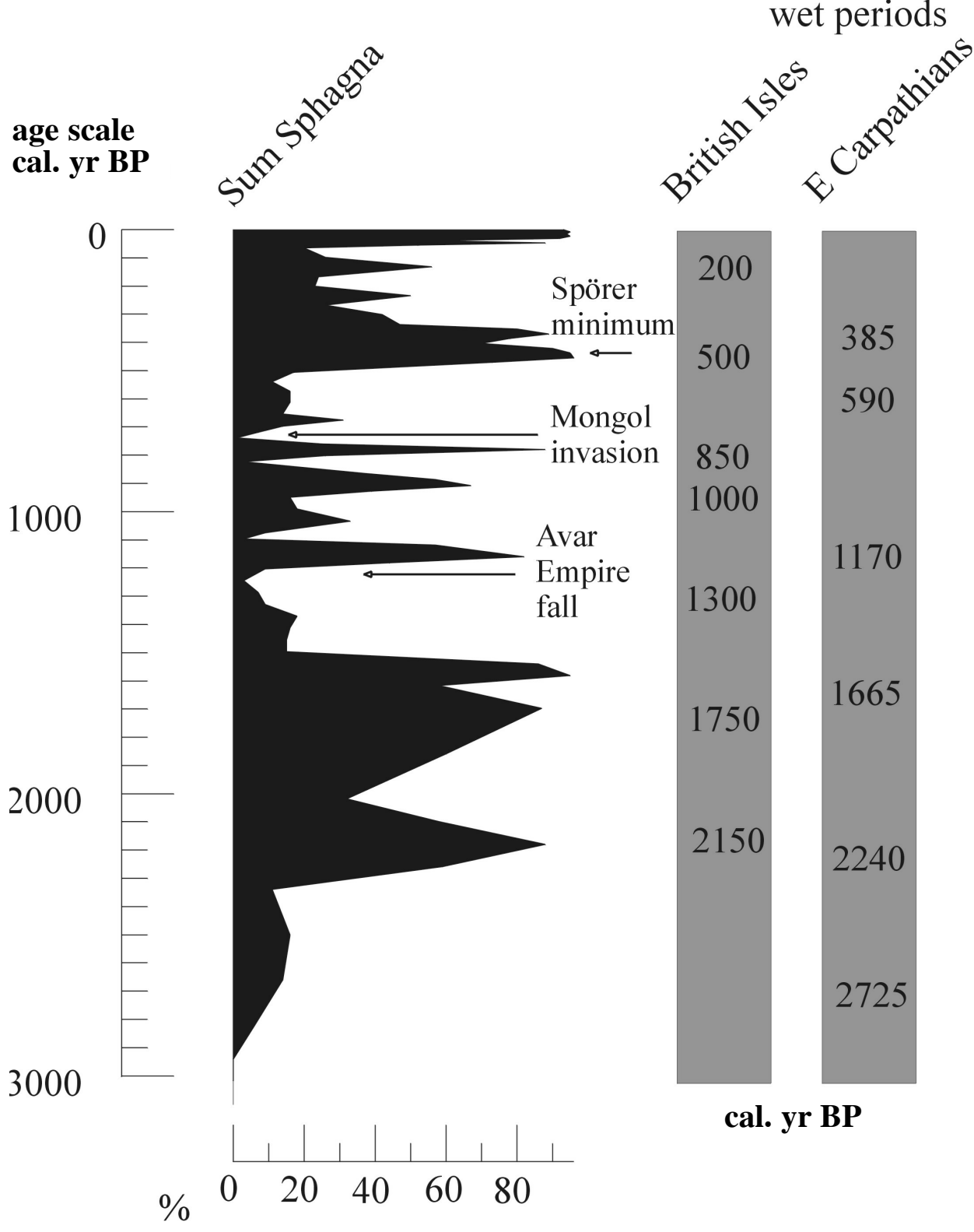

Fig. 5

Comparison of bog surface wetness changes of the Sirok Nyírjes-tó and some British (Barber et al. 1994; Mauquoy and Barber 1999) and Romanian (Schnitchen et al. 2006) peat bogs in the last 3000 years. The arrows show some historical events 
ecological data for the Nyíres-tó peat bog, Hungary was characterized by extremely warm conditions during this period, resulting in an almost complete dessication of the Sphagnum peatland.

The Sphagnum curve of the Nyíres-tó enables us to identify the period of the Little Ice Age (LIA), dated between the middle part of the 16th century till the middle part of the 19th century (Pfister 1999; Pfister and Brázdil 1999; Bradley et al. 2003). The environmental record for the Nyírjes-tó peat bog fits with these events as well. The most diverse Sphagnum taxa, including the hygrophilous Sphagnum cuspidatum, was present here at the end of the 16th century. Sphagnum cuspidatum does not currently occur in the Nyírjes-tó. Western European peatlands were similarly prone to the fluctuating climate of the LIA (Mauquoy et al. 2002). Wetter conditions were identified from the beginning of the 16th and middle part of the 17th centuries. LIA climate deterioration can be detected in several proxy-climate records in the Carpathian Basin as well. Based on the Eastern Carpathian tree-ring width chronology of Popa and Kern (2009) the fingerprint of the LIA is visible between AD 1370 and 1630, followed by lagged cold decades in AD 1820 and 1840. Tree-ring data between AD 1460 and 1510 strongly correlated with Alpine reconstructions. This suggests strong regional forcing predominant over the eastern Carpathians and the Alps, producing a uniquely European signal. The high-resolution stable isotope and trace element records from a stalagmite from Hungary showed that during the LIA, the coldest years (longer or colder winters) occurred from around AD 1550 to ca. 1700 (Siklósy et al. 2009).

\section{Conclusions}

According to Blaauw et al. (2004) there is a strong relationship between the moisture gradient of peatlands and solar activity reflected in the correlation of the former parameter with a proxy for $\delta^{14} \mathrm{C}$. One may properly ask what component of the climate controls the moisture gradient of peatlands via fluctuating solar activities? Surficial wetness is controlled by a complex interplay of precipitation and evapotranspiration of the plants, seen in such parameters as annual average rainfall and evaporation and influenced by the temperatures of the growth season. There are no surficial water courses feeding the Nyírjes-tó peat bog, so runoff must have been influential only during the past 100 years on the hydrology of the peatland.

As was shown in western Europe the moisture gradient of peatlands for the past 3000 years was primarily determined by fluctuations in the temperature of the vegetation season, rather than the amout of rainfall (Barber et al. 2000; Barber and Langdon 2001, 2007; Barber and Charman 2005; Schoning et al. 2005; Charman et al. 2009; Swindles et al. 2010). According to Charman (2007), in the Atlantic part of Europe summer precipitation and summer temperatures control the moisture gradient of peatlands. The pollen-based climate reconstructions 
from the eastern Carpathians (Feurdean et al. 2008) suggest that summer temperatures between 11200 and $8300 \mathrm{cal}$. yr BP were similar to those of the present. Between 8000 and 2400 cal. yr BP summer temperatures were higher than now. Pollen-based climate reconstructions indicated that summer temperatures became cooler in the last 2400 years. It seems that these general trends of summer temperatures determined the surface wetness history of the Nyírjes-tó peat bog. The relationships to other climatic parameters (e.g. annual precipitation, annual and winter temperature) investigated by Feurdean et al. (2008) are conflicting.

Unfortunately, macrofossil studies are not acapable to accurately predict former temperatures or precipitation rates. Only the major trajectories of climate changes can be identified. The modern distribution of Sphagnum peatlands in Hungary enable us to provide a rough estimate. Sphagnum peatlands appear in areas characterized by a precipitation of $600 \mathrm{~mm}$ per annum. Below this threshold one comes across only sporadic occurrences, while there are no Sphagna known below the lower limit of $550 \mathrm{~mm}$. Based on the results for the Nyírjes-tó peat bog conditions in the lower hilly areas during the drier periods of the past 3000 years may be inferred to have been similar to those of the central parts of the GHP. The complete disappearance of Sphagna from the area must be linked to a steady drop in rainfall, resulting in an least $50 \mathrm{~mm}$ deficit in the local water balance. This could have been achieved by an increased evapotranspiration as a result of elevated temperatures of the summer growth season. This deficit value must have exceeded even $100 \mathrm{~mm}$ during the Middle Holocene Transition.

\section{Acknowledgements}

The primary author of this paper is grantee of the János Bolyai Scholarship. The reviews by Minna Väliranta and an anonymous reviewer helped improve the paper and are gratefully acknowleged.

\section{References}

Aaby, B. 1976: Cyclic climatic variations in climate over the past 5,500 yrs reflected in raised bogs. Nature, 263, pp. 281-284.

Aaby, B., G. Digerfeldt 1986: Sampling techniques for lakes and bogs. - In: Berglund, B.E. (Ed.): Handbook of Holocene Palaeoecology and Palaeohydrology, John Wiley and Sons Ltd. pp. 181-194.

Alley, R.B., A.M. Ágústsdóttir 2005: The 8k event: cause and consequences of a major Holocene abrupt climate change. - Quaternary Science Reviews, 24/10-11, pp. 1123-1149.

Alley, R.B., P.A. Mayewski, P.T. Sowers, M. Stuiver, K.C. Taylor, P.U. Clark 1997: Holocene climatic instability; a prominent, widespread event 8200 yr ago. - Geology, 25, pp. 483-486.

Bacsó, N. 1959: Magyarország éghajlata (Climate of Hungary). - Akadémiai Kiadó, Budapest, 302 p.

Barber, K.E. 2007: Peatland records of Holocene climate change. - In: Elias, S.A. (Ed.): Encyclopedia of Quatermary Science, Vol. 3, Elsevier, pp. 1883-1894. 
Barber, K.E., F.M. Chambers, D. Maddy, J. Brew 1994: A sensitive high resolution record of the Holocene climatic change from a raised bog in northern England. - The Holocene, 4, pp. 198-205.

Barber, K.E., D. Charman 2005: Holocene palaeoclimate records from peatlands. - In: Mackay, A., R. Battarbee, J. Birks, F. Oldfield (Eds): Global Change in the Holocene, Hodder Arnold, pp. 210-226.

Barber, K.E., P.G. Langdon 2001: Peat stratigraphy and climate change. - In: Brothwell, D.R., A.M. Pollard (Eds): Handbook of Archaeological Sciences, Wiley, Chicester, pp. 155-166.

Barber, K.E., P.G. Langdon 2007: What drives the peat-based palaeoclimate record? A critical test using multi-proxy climate records from nothern Britain. - Quat. Sci. Rev., 26, pp. 3318-3327.

Barber, K.E., D. Maddy, N. Rose, A.C. Stevenson, R. Stoneman, R. Thompson 2000: Replicated proxy-climate signals over the last $2000 \mathrm{yr}$ from two distant UK peat bogs: new evidence for regional palaeoclimate teleconnections. - Quat. Sci. Rev., 19, pp. 481-487.

Bennett, K.D. 1992: PSIMPOLL - A quickBasic program that generates PostScript page description of pollen diagrams. - INQUA Commission for the study of the Holocene: working group on data handling methods, Newsletter 8, pp. 11-12.

Birks, H.H. 2007: Plant macrofossil introduction. - In: Elias, S.A. (Ed.): Encyclopedia of Quaternary science, Vol. 3, Elsevier, pp. 2266-2288.

Blaauw, M., B. van Geel, J. van der Plicht 2004: Solar forcing of climatic change during the midHolocene: indicators from raised bogs in The Netherlands. - The Holocene, 14/1, pp. 35-44.

Blackford, J. 2000: Palaeoclimatic records from peat bogs. - Trends in Ecology and Evolution, 15/5, pp. 193-198.

Blytt, A. 1876: Essays on the Immigration of Norwegian Flora during Alternating Rainy and Dry Periods. - Kristiana Cammermeyer, 89 p.

Bond, G., W. Showers, M. Cheseby, R. Lotti, P. Almasi, P. deMenocal, P. Priore, H. Cullen, I. Hajdas, G. Bonani 1997: A pervasive millenial-scale cycle in North Atlantic Holocene and glacial climates. - Science, 278, pp. 1257-1266.

Borhidi, A., A. Sánta (Eds) 1999: Vörös könyv Magyarország növénytársulásairól 1-2 (Red book of plant communities in Hungary). - Természetbúvár Alapítvány Kiadó, Budapest, 362 p, 404 p.

Boros, Á. 1968: Bryogeographie und Bryoflora Ungarns. - Akadémiai Kiadó, Budapest, 466 p.

Bradley, R.S., M.K. Hughes, H.F Diaz 2003: Climate in medieval time. - Science, 302, pp. 404-405.

Buczkó, K., E.K. Magyari, P. Bitusik, A. Wacnik 2009: Review of dated Late Quaternary palaeolimnological records in the Carpathian Region, east-central Europe. - Hydrobiologia, 631/1, pp. 3-28.

Charman, D.J. 2007: Summer water deficit controls on peatland water table changes: implications for Holocene palaeoclimate reconstructions. - The Holocene, 17/2, pp. 217-227.

Charman, D.J., K.E. Barber, M. Blaauw, P.G. Langdon, D. Mauquoy, TJ. Daley, P.D.M. Hughes, E. Karofeld 2009: Climate drivers for peatland palaeoclimate records. - Quaternary Science Reviews, 28/19-20, pp. 1811-1819.

Cheddadi, R., G. Yu, J. Guiot, S.P. Harrison, I.C. Prentice 1997: The climate of Europe 6000 years ago. - Climate Dynamics, 13, pp. 1-9.

Davis, B.A.S., S. Brewer, A.C. Stevenson, J. Guiot Data Contributors 2003: The temperature of Europe during the Holocene reconstructed from pollen data. - Quaternary Science Reviews, 22, pp. 1701-1716.

Feurdean, A., S. Klotz, V. Mosbrugger, B. Wohlfarth 2008: Pollen-based quantitative reconstructions of Holocene climate variability in NW Romania. - Palaeogeography, Palaeoclimatology, Palaeoecology, 260, pp. 494-504.

Gardner, A.R. 2002: Neolithic to Copper Age woodland impacts in northeast Hungary? Evidence from the pollen and sediment chemistry records. - The Holocene, 12, pp. 521-553.

Grosse-Brauckmann, G., W. Haussner, K. Mohr 1973: Über eine kleine Vermoorung im Odenwald, ihre Ablagerungen und ihre Entwicklung der umgebenden Kulturlandschaft. - Z. Kulturtechnik und Flurbereinigung, 14, pp. 132-143. 
Györffy, Gy. 1995: Hová lettek az avarok? (Where did the Avars go?) - História, 17/3, pp. 3-9.

Györffy, Gy., B. Zólyomi 1994: A Kárpát-medence és Etelköz képe egy évezred előtt (The people of the Carpathian Basin and Etelköz 1000 years ago). pp. 13-37. - In: Györffy, Gy., L. Kovács (Eds): Honfoglalás és régészet (Hungarian Conquest and Archaeology). Balassi Kiadó, Budapest.

Haas, J.N., I. Richoz, W. Tinner, L. Wick 1998: Synchronous Holocene climatic oscillations recorded on the Swiss Plateau and at the timberline in the Alps. - The Holocene, 8, pp. 301-304.

Hughes, P.D.M., D. Mauquoy, K.E. Barber, P.G. Langdon 2000: Mire development pathways and palaeoclimatic records from a full Holocene peat archive at Walton Moss, Cumbria, England. The Holocene, 10, pp. 465-479.

lizuka, Y., T. Hondoh, Y. Fujii 2008: Antarctic sea ice extent during the Holocene reconstructed from inland ice core evidence. - Journal of Geophysical Research, 113. D15114 doi:10.1029/2007JD009326

Jakab, G., P. Majkut, I. Juhász, S. Gulyás, P. Sümegi, T. Törő́csik 2009: Palaeoclimatic signals and anthropogenic disturbances from the peat bog at Nagybárkány (N Hungary). - Hydrobiologia, 631/1, pp. 87-106.

Jakab, G., P. Sümegi, E. Magyari 2004a: A new palaeobotanical method for the description of Late Quaternary organic sediments (Mire-development pathways and palaeoclimatic records from $S$ Hungary). - Acta Geologica Hungarica, 47/4, pp. 1-37.

Jakab, G., P. Sümegi, Zs. Szántó 2005: Késő-glaciális és holocén vízszintingadozások a Szigligetiöbölben (Balaton) makrofosszília vizsgálatok eredményei alapján [Late Glacial and Holocene water level changes in the bay of Szigliget (Balaton Lake) based on the results of the macrobotanical investigations]. - Földtani Közlöny, 135/3, pp. 405-431.

Jakab, G., P. Sümegi 2004b: A lágyszárú növények tőzegben található maradványainak határozója mikroszkópikus bélyegek alapján (Keys and descriptions for the determination of fossil plant remains occure in peat). - Kitaibelia 9/1, pp. 93-129.

Jakab, G., P. Sümegi 2007: The vegetation history of Baláta-tó. - In: Juhász, I.E., Cs. Zatykó, P. Sümegi (Eds): Environmental History of Transdanubia, Varia Archaeologica Hungarica, 20, pp. 251-254.

Joerin, U.E., K. Nicolussi, A. Fischer, T.F. Stocker, C. Schlüchter 2008: Holocene optimum events inferred from subglacial sediments at Tschierva Glacier, Eastern Swiss Alps. - Quaternary Science Reviews, 27, pp. 337-350.

Jowsey, P.C. 1966: An improved peat sampler. - New Phytologist, 65, pp. 245-248.

Kiss, A. 2000: Weather events during the first Tartar invasion in Hungary 1241-42). - Acta Geographica Szegediensis, 37, pp. 149-156.

Kiss, A. 2003: "Ecce, in hyemis nivis et glaciei habundantia supervenit" - Időjárás, környezeti krízis és a tatárjárás (Meteorology, environmental crisis and the invasion of the Mongols). - In: Nagy, B. (Ed.): Tatárjárás (Invasion of the Mongols). Osiris Kiadó, Budapest, pp. 439-452.

Lájer, K. 1998: Bevezetés a magyarországi lápok vegetáció-ökológiájába (Introduction to the vegetation ecology of the peatbogs in Hungary). - Tilia, 6, pp. 84-238.

Magny, M. 1998: Reconstruction of Holocene lake-level changes in the Jura (France): methods and results. - In: Harrison, S.P., B. Frenzel, U. Huckried, M. Weiss (Eds): Palaeohydrology as Reflected in Lake-level Changes as Climatic Evidence for Holocene Times, Paläoklimaforschung, 25, pp. 67-85.

Magny, M., U. Leuzinger, S. Bortenschlager, J.N. Haas 2006: Tripartite climate reversal in Central Europe 5600-5300 years ago. - Quaternary Research, 65, pp. 3-19.

Magny, M., C. Miramont, O. Sivan 2002: Assessment of climate and antropogenic factors on Holocene Mediterranean vegetation in Europe on the basis of palaeohydrological records. Palaeogeography, Palaeoclimatology, Palaeoecology, 186, pp. 47-59.

Magny, M., P. Schoellammer 1999: Lake-level fluctuations at Le Locle, Swiss Jura, from the Younger Dryas to the Mid-Holocene: A high-resolution record of climate oscillations during the final deglaciation. - Géographie Physique et Quaternaire, 53/2, pp. 183-197. 
Magyari, E., P. Sümegi, M. Braun, G. Jakab, M. Molnár 2001: Retarded wetland succession: anthropogenic and climatic signals in a Holocene peat bog profile from north-east Hungary. Journal of Ecology, 89, pp. 1019-1032.

Magyari, E., K. Buczkó, G. Jakab, M. Braun, Zs. Szántó, M. Molnár, Z. Pál, D. Karátson 2006: Holocene palaeohydrology and environmental history in the South Harghita Mountains, Romania. - Földtani Közlöny, 136/2, pp. 249-284

Magyari, E.K., K. Buczkó, G. Jakab, M. Braun, Z. Pál, D. Karátson 2009:. Palaeolimnology of the last Eastern Carpathian crater lake - a multiproxy study of Holocene hydrological changes. Hydrobiologia, 631/1, pp. 29-63.

Magyari, E.K., J.C. Chapman, D.G. Passmore, J.R.M. Allen, J.P. Huntley, B. Huntley 2010: Holocene persistence of wooded steppe in the northern Great Hungarian Plain. - Journal of Biogeography, 37, pp. 915-935.

Máthé, I., M. Kovács 1958: A Mátra tôzegmohás lápja (The peatbog of Mátra). - Botanikai Közlemények, 47/3-4, pp. 323-331.

Mauquoy, D., K. Barber 1999: A replicated 3000 yr proxy-climate record from Coom Rigg Moss and Felicia Moss, The Border Mires, northern England. - Journal of Quaternary Science, 14/3, pp. 263-275.

Mauquoy, D., B. van Geel 2007: Mire and peat macros. - In: Elias, S.A. (Ed.): Encyclopedia of Quatermary science, Vol. 3. Elsevier, pp. 2315-2336.

Mauquoy, D., B. van Geel, M. Blaauw, J. van der Plicht 2002: Evidence from northwest European bogs shows 'Little Ice Age' climatic changes driven by variations in solar activity. - The Holocene, 12/1, pp. 1-6.

Nesje, A., S.O. Dahl 2001: The Greenland 8200 cal. yr BP event detected in loss-on-ignition profiles in Norwegian lacustrine sediment sequences. - Journal of Quaternary Science, 16/2, pp. $155-166$.

Oldfield, F. 2005: Environmental Change: Key Issues and Alternative Approaches. - Cambridge University Press, Cambridge, $363 \mathrm{p}$.

Penksza, K., G. Turcsányi, M. Kovács 1994: A siroki Nyírjes-tó tőzegmohalápjának elemkatasztere (Element concentration cadasters of peat profiles in Nyírjes bog near Sirok in Hungary). Botanikai Közlemények, 81/1, pp. 29-41.

Pfister, C. 1999: Wetternachhersage: 500 Jahre Klimavariationen und Naturkatastrophen (1496-1995). - Haupt: Bern. 304 p.

Pfister, C., R. Brázdil 1999: Climatic variability in sixteenth-century Europe and its social dimension: A synthesis. - Climatic Change, 43/1, pp. 5-53.

Popa, I., Z. Kern 2009: Long-term summer temperature reconstruction inferred from tree-ring records from the Eastern Carpathians. - Climate Dynamics, 32, pp. 1107-1117.

Rybnícek, K., E. Rybnícková 1974: The origin and development of waterlogged meadows in the central part of the Sumava Foothills. - Folia Geobot. Phytotax., 9, pp. 45-70.

Rybnícková, E. 1974: Die Entwicklung der Vegetation und Flora im Südlichen Teil der BöhmischMährischen Höhe während des Spätglacial und Holozäns. - Vegetace CSSR, 7, pp. 1-163.

Schnitchen, C., E. Magyari, B. Tóthmérész, I. Grigorszky, M. Braun 2003: Micropaleontological observations on a Sphagnum bog in East Carpathian region - testate amoebae (Rhizopoda: Testacea) and their potential use for reconstruction of micro- and macroclimatic changes. Hydrobiologia, 506/1-3, pp. 45-49.

Schnitchen, Cs., D.J. Charman, E. Magyari, M. Braun, I. Grigorszky, B. Tóthmérész, M. Molnár, Zs. Szántó 2006: Reconstructing hydrological variability from testate amoebae analysis in Carpathian peatlands. - Journal of Paleolimnology, 36, pp. 1-17.

Schoning, K., D.J. Charman, S. Wastegard 2005: Reconstructed water tables from two ombrotrophic mires in eastern central Sweden compared with instrumental meteorological data. - The Holocene, 15, pp. 111-118.

Sernander, R. 1908: On the evidence of postglacial changes of climate furnished by the peat-mosses of northern Europe. - Geol. Fören. Stockh. Förh., 30, pp. 467-478. 
Preliminary data on the bog surface wetness from the Sirok Nyírjes-tó peat bog, Mátra Mts, Hungary 65

Siklósy, Z., A. Demény, I. Szenthe, Sz. Leél-Össy, S. Pilet, Y. Lin, C. Shen 2009: Reconstruction of climate variation for the last millennium in the Bükk Mountains, northeastern Hungary, from a stalagmite record. - Időjárás, 113/4, pp. 245-263.

Sümegi, P. 2007: The sediment sequence from Mezőlak. - In: Zatykó, Cs., I. Juhász, P. Sümegi (Eds) Environmental Archaeology in Transdanubia (Hungary). Varia Archaeologica Hungarica, 20, pp. 403-404, Budapest.

Sümegi, P., S. Gulyás, G. Jakab 2008: Holocene paleoclimatic and paleohydrological changes in Lake Balaton as inferred from a complex quantitative environmental historical study of a lacustrine sequence of the Szigliget embayment. - Documenta Praehistorica, 35, pp. 33-43.

Sümegi, P., G. Ilon, G. Jakab, D.G. Páll, T. Törőcsik 2009a: Neolit és rézkori régészeti kultúrák és környezeti hátterük az Alpokaljáról (Neolithic and Copper Age cultures and their backgrounds from Subalpine region of Hungary). pp. 189-195. - In: Bende, L., G. Lórinczy (Eds): Medinától Etéig (From Medina to Ete). Régészeti Tanulmányok Csalog József születésének 100. évfordulójára. Koszta József Múzeum Kiadványa, Szentes.

Sümegi, P., G. Jakab, P. Majkut, T. Törőcsik, Cs. Zatykó 2009b: Middle Age paleoecological and paleoclimatological reconstruction in the Carpathian Basin. - Időjárás, 113, pp. 265-298.

Swindles, G.T., A. Blundell, H.M. Roe, V.A. Hall 2010: A 4500-year proxy climate record from peatlands in the Noth of Ireland: the identification of widespread summer 'drought phases'? Quat. Sci. Rev., 29/13-14, pp. 1577-1589.

Szurdoki, E. 2005: Magyarországi tôzegmohafajok elterjedése és egyes fajok vízkémiai igényének vizsgálata. (Distribution of Hungarian peat mosses and investigation of water chemical relation of some species). - PhD thesis, L. Eötvös University, Budapest (mscr.)

Szurdoki, E., J. Nagy 2002: Sphagnum dominated mires and Sphagnum occurrences of NorthHungary. - Folia Historico Naturalia Musei Matrensis, 26, pp. 67-84.

Troels-Smith, J. 1955: Karakterisering af lose jordater. - Danmarks Geologiske Undersogelse, 4/3, pp. $1-73$.

Väliranta, M., A. Korhola, H. Seppä, E. Tuittila, K. Sarmaja-Korhonen, J. Laine, J. Alm 2007: High resolution reconstruction of wetness dynamics in southern boreal raised bog, Finland, during the late Holocene: a quantitative approach. - The Holocene, 17/8, pp. 1093-1107.

Weninger, B., O. Jöris, U. Danzeglocke 2008:. CalPal-2007. Cologne, Radiocarbon Calibration \& Palaeoclimate Research Package. - http://www.calpal.de/, accessed 2008-01-10. 